\title{
SCREENING ASSESSMENT OF CYANOBACTERIAL EMBRYOTOXICITY TO JAPANESE MEDAKA, ORYZIAS LATIPES (ACTINOPTERYGII: BELONIFORMES: ADRIANICHTHYIDAE)
}

\author{
Zdeněk ADÁMEK ${ }^{1 *}$, Jiří SIKORA ${ }^{1}$, Luděk BLÁHA², Blahoslav MARŠÁLEK ${ }^{3}$ \\ $1^{*}$ University of South Bohemia in České Budějovice, Faculty of Fisheries and Protection of Waters, \\ South Bohemian Research Center for Aquaculture and Biodiversity of Hydrocenoses \\ and Research Institute of Fish Culture and Hydrobiology, Vodñany, Czech Republic \\ ${ }^{2}$ Masaryk University, Faculty of Science, Research Centre for Toxic Compounds in the Environment (RECETOX), \\ Kamenice 3, 62500 Brno, Czech Republic \\ ${ }^{3}$ Department of Experimental Phycology and Ecotoxicology, Institute of Botany, Czech Academy of Sciences, \\ Lidická 25/27, 65700 Brno, Czech Republic
}

\begin{abstract}
Adámek Z., Sikora J., Bláha L., Maršálek B. 2011. Screening assessment of cyanobacterial embryotoxicity to Japanese medaka, Oryzias latipes (Actinopterygii: Beloniformes: Adrianichthyidae). Acta Ichthyol. Piscat. 41 (4): 293-299.
\end{abstract}

Background. Fish embryos and larvae are frequently subject to chronic- and damaging exposure of cyanotoxins released by live and decomposing cyanobacteria Whereas the majority of former studies dealt with the embryotoxicological effects of pure toxins and extracts, we focused on the evaluation of toxic effects of crude cyanobacterial biomass in our study.

Materials and methods. Samples of crude cyanobacterial biomass - intended for embryotoxicological tests with eggs of Japanese medaka, Oryzias latipes (strain Q2d-rR.YHNI) - were collected from natural bodies of water in the Czech Republic. Those samples consisted predominantly of: Microcystis aeruginosa, M. flos-aquae, Woronichinia naegeliana, Anabaena sigmoidea, and Aphanizomenon flos-aquae. In the preliminary optimization experiments, various numbers of fertilized medaka eggs (from 1 to 6 per one $10-\mathrm{mL}$ well on a six well polypropylene plate) were hatched under standard conditions. Because of the highest hatching rates, 4 eggs per $10 \mathrm{~mL}$ well were selected as an optimal treatment. The embryotoxicological tests were performed according to the OECD 212 guideline in two concentrations (extracts of crude cyanobacterial biomass: 40 and $200 \mathrm{mg} \cdot \mathrm{L}^{-1}$ dry weight). Fertilized eggs in stage 6 to 8 (some $2-3 \mathrm{~h}$ after fertilization) were introduced into test wells, and hatching performance, duration of embryonic development as well as lethal and sublethal effects were monitored.

Results. The hatching rates (treatment with 4 eggs per $10 \mathrm{~mL}$ well), achieved in the majority of experimental treatments with cyanobacterial biomass, were significantly different from the control group. Also hatching onset was considerably delayed due the presence of cyanobacterial biomass. The embryotoxicological impacts were more pronounced in higher concentrations of cyanobacterial biomass $\left(200 \mathrm{mg} \cdot \mathrm{L}^{-1}\right)$ compared to lower concentrations $\left(40 \mathrm{mg} \cdot \mathrm{L}^{-1}\right)$. Whilst deformities were not recorded in the control, their highest incidence amounted to $11.8 \%$ and $40.9 \%$ in 40 and $200 \mathrm{mg} \cdot \mathrm{L}^{-1}$ of cyanobacterial biomass, respectively.

Conclusion. Cyanotoxicity significantly affected examined parameters (hatching rates, duration of embryonic development, and morphological deformities occurrence) in medaka embryos. The study proved significant embryotoxic effects upon Japanese medaka at environmentally relevant levels of cyanobacteria commonly occurring in surface waters in Europe.

Keywords: Oryzias latipes cyanobacteria embryonic development cyanotoxins embryotoxicity

\section{INTRODUCTION}

Within the recent decades the blooms of cyanobacteria (blue green algae) in open waters have been creating serious ecological, hygienic, and sanitary problems dis- turbing the stability of inland water ecosystems and threatening human and animal health. Their occurrence radically limits the use of affected water bodies for recreation, drinking water abstraction, fisheries, and many 
other related human activities. The impacts of cyanotoxins produced by dominating cyanobacteria species upon various components of water environment and human and animal physiology (and many other aspects) are in focus of interest of many scientific institutions all over the world. Densely concentrated scum of cyanobacteria occurs often in shallow littoral zones which are primarily hatching- and nursing areas for fish and amphibian early life stages. Thus fish and amphibian embryos and larvae are frequently subject to chronic exposure of cyanotoxins released by live and decomposing cyanobacterial biomass which may result in serious damages (Burýšková et al. 2006). While instrumental chemical methods are used to quantify the cyanotoxin concentrations, bioassays are widely used to study and confirm their toxic action.

From the point of view of an organism during its ontogeny, early developmental stages of fish and other aquatic animals are especially vulnerable to the impact of toxic substances with possible considerable negative effects. Cyanobacterial toxins belong among bioactive compounds that pose growing threats to human and environmental health and thus, they are of currently increasing interest focused upon the physiological, behavioural and developmental responses of aquatic life (Oberemm et al. 1999, Jacoby et al. 2000, Maršálek et al. 2000, Bischoff 2001).

The concentrations of microcystins in cyanobacterial biomass from eutrophic and hypertrophic Czech water bodies may reach up to $4.45 \mathrm{mg} \cdot \mathrm{g}^{-1}$ dry weight (Maršálek et al. 2001) which makes the necessity for the rapid screening evaluation of their toxicity highly desirable.

In the presently reported study, we optimized and used a model with Japanese medaka for screening of cyanobacterial embryotoxicity. Japanese medaka, Oryzias latipes, eggs were selected for the purposes of screening evaluation due to several reasons:

- Fish embryos represent an excellent model for environmental risk assessment based on small scale, highthroughput analyses (Scholz et al. 2007);

- Medaka embryos are good model for monitoring toxic effects of aquatic pollution and their rapid development and transparent chorion allow embryogenesis to be easily followed (Jacquet et al. 2004);

- High sensitivity of medaka fish to subacute exposure of microcystin contamination has been demonstrated (Djediat et al. 2010);

- The other routine non-specific pre-screening microbiotests suffer from various problems caused by low correlation with the dose tested (bacteria), interpretation problems and/or lack of oxygen (crustaceans and protozoans);

- The use of fish embryos is not regulated by current legislation on animal welfare and it is therefore considered as a refinement, if not replacement of animal experiments (Maršálek and Bláha 2000).

Immersion embryotoxicity tests of cyanobacteria (and their toxins) are considered as low effective (Oberemm et al. 1997) because the chorion of medaka egg acts as a potential protective barrier to water-soluble toxins and only very high concentrations resulted in deleterious effects.
The limitations of direct ambient environmental exposure of fish embryos to toxicant may be overcome by microinjection. Several investigators utilized this approach in studies of cyanobacterial toxicity (Helmstetter et al. 1996, Jacquet et al. 2004, Huynh-Delerme et al. 2005, Lecoz et al. 2008), however, in contrast to the results with medaka embryos, the immersion exposure induced an array of embryonic abnormalities in zebrafish, Danio rerio (see Berry et al. 2007), and embryos of loach, Misgurnus mizolepis (see Liu et al. 2002).

Thus the objective of laboratory immersion screening toxicity tests, presented in this study, was to estimate how the embryos of Japanese medaka, Oryzias latipes, respond to crude cyanobacterial biomass from natural bodies of water during the whole embryonic development commencing 2-3 h after fertilization until their hatching.

\section{MATERIAL AND METHODS}

Broodfish culture and egg collection. The broodfish (Q2d-rR.YHNI strain) originated from the laboratory culture of the Department of Zoology, TU Dresden, Germany. Pre-spawning culture was maintained in glass aquaria $(600 \times 400 \times 400 \mathrm{~mm}, 100 \mathrm{~L}$ volume $)$ equipped with necessary heating, filtering, aeration and lightening systems. A bunch of Java moss (Vesicularia dubyana) was inserted to provide a substrate for egg deposition by spontaneously spawning females. Broodfish were fed daily with frozen zooplankton supplemented with dry feed mixture Sera Microgran (Sera, Heinsberg, Germany). Water temperature was maintained at $25 \pm 1{ }^{\circ} \mathrm{C}$. The $15 \mathrm{~h} / 9 \mathrm{~h}$ light/dark regime (white $20 \mathrm{~W}$ fluorescent tube) was kept automatically to provide successful spawning induction. For the experimental purposes, fish spawning was performed in single pairs in 6 -L glass aquaria $(340 \times 160 \times$ $160 \mathrm{~mm}$ ) containing small bunch of Java moss. Four spawning aquaria were inserted into a large 100-L aquarium to provide constant identical conditions. For tests of embryotoxicity, fish spawning was performed in groups consisting of 8 females and 16 males. Fish stocked for spawning were daily fed with live artemia (Artemia salina) nauplii.

Eggs were collected early in the morning, within 2-3 h after spawning (stage 5 to 6 ). The eggs were collected from anesthetized (Clove Leaf Oil, Purity Australia Pty. Ltd., Australia; $2 \mu \mathrm{L}$ per 50-mL Petri dish) females. Each individual egg was checked microscopically for possible damages under $40 \times$ magnification before the test.

Optimization of egg numbers in a testing well. Before the embryotoxicity evaluation, the tests on assessment of optimal egg number per incubation well $(10 \mathrm{~mL})$ were performed. During the experiments, 6-well polypropylene well plates $(250 \times 200 \times 30 \mathrm{~mm}$, Nalge Nunc International, USA) were placed in a small incubator with controlled temperature regime $\left(25 \pm 1^{\circ} \mathrm{C}\right)$ and $15 \mathrm{~h} / 9 \mathrm{~h}$ light/dark regime. The eggs were transferred into experimental wells in numbers from one (A) to six $(F)$ per well.

Test duration was limited by hatching of the last embryo in a well. Tests were performed as static, i.e., without exchange of incubation medium which was pre- 
pared according to ISO 7346-1 (Anonymous 1999a) protocol. The wells were checked daily and dead embryos were immediately removed and recorded. The parameters monitored were (1) hatching rate, (2) duration of embryonic development, and (3) malformation occurrence (Helmstetter et al. 1996, Jacquet et al. 2004).

Cyanobacterial biomass toxicity tests. Altogether, six samples (1A-3A, 1B-3B) of cyanobacterial biomass (Table 1) originating from two reservoirs located on the Ohře River (NW Bohemia, Czech Republic): Nechranice $\left(50^{\circ} 21^{\prime} \mathrm{N}, 13^{\circ} 24^{\prime} \mathrm{E}\right)$ on 31 July 2004 (1) and 11 September 2004 (2), and Újezd $\left(50^{\circ} 30^{\prime} \mathrm{N}, 13^{\circ} 28^{\prime} \mathrm{E}\right)$ on 31 June 2004 (3) were tested. The ISO 7346-2 incubation medium (Anonymous 1999b), which was used for dilution of cyanobacterial biomass, served as a control. Each sample was tested in 12 replicates. Description of the samples is shown in Table 2. The contents of chlorophyl- $a$ and microcystins were determined according to Gregor and Maršálek (2004) and Babica et al. (2006), respectively. In microcystins: -LR, -YR, -RR (MC-LR, MC-YR, MC-RR), the letters LR, YR and RR indicate aminoacids at two variable positions in the microcystin peptide structure.

Crude complex cyanobacterial biomass, stored for 4 months at $-18^{\circ} \mathrm{C}$ was homogenized by sonification using ultrasound disintegrator Bandelin Sonoplus HD2070. The homogenates were deeply re-frozen again and stored at $-18^{\circ} \mathrm{C}$ until embryotoxicity test procedures. Before the addition of the incubation medium, samples were pre-incubated at $25^{\circ} \mathrm{C}$ and 10 -min homogenized on the Vortex equipment. Two concentrations (A and B, corresponding to 40 and $200 \mathrm{mg}$ dry weight (dw) of cyanobacterial biomass per $1 \mathrm{~L}$ ) were adjusted for the test procedures. The microcystin (MC) content in particular samples ranged from 80.9 to $1670.2 \mu \mathrm{g} \cdot \mathrm{g}^{-1} \mathrm{dw}$ (Table 1).

The experimental screening tests followed the OECD 212 (Anonymous 1998) standard protocol aimed at the evaluation of hatching rates (in \%), embryonic development span (in degree-days, $\mathrm{D}^{\circ}$ ) and malformation occurrence (in \%), i.e., both deformities (yolk sac dropsy, gas bladder non-inflation, tail spinal curvature, liver and gallbladder tumors) estimated on eleuter embryos and unhatched/dead eggs. The tests were performed by semistatic method at $25^{\circ} \mathrm{C}$ with tested media exchange each 48 and $24 \mathrm{~h}$ in concentrations 40 and $200 \mathrm{mg} \cdot \mathrm{L}^{-1}$, respectively. The oxygen saturation dropped (in average) to $70 \%$ and $66 \%$ for lower and higher sample concentration (A and B), respectively. Ambient conditions in the incubator were adjusted at $25 \pm 1^{\circ} \mathrm{C}$ and $15 \mathrm{~h} / 9 \mathrm{~h}$ light/dark regime. Four fertilized eggs were hatched in $10-\mathrm{mL}$ wells in 6-well polypropylene plates in twelve replicates and checked daily at $0800 \mathrm{~h}$ and $2000 \mathrm{~h}$ under stereomicroscope $(25 \times$ magnification). The hatching media were exchanged after the evening control. Dead eggs were removed, and hatched larvae were immediately transferred into ISO 7346-1 incubation medium (static test procedure) (Anonymous 1999a) for further control until the start of the exogenous feeding, i.e., usually the second day after hatching. Oxygen content was checked daily by YSI

Table 1

Microcystin (MC) content of the crude cyanobacterial biomass, sampled from natural water bodies in the Czech Republic, and used for toxicity tests performed on Japanese medaka, Oryzias latipes

\begin{tabular}{lccccc}
\hline Sample No. & $\begin{array}{c}\text { Dry weight } \\
{\left[\mathrm{mg} \cdot \mathrm{L}^{-1}\right]}\end{array}$ & $\begin{array}{c}\text { MC-LR } \\
{\left[\mu \mathrm{g} \cdot \mathrm{L}^{-1}\right]}\end{array}$ & $\begin{array}{c}\mathrm{MC}-\mathrm{YR} \\
{\left[\mu \mathrm{g} \cdot \mathrm{L}^{-1}\right]}\end{array}$ & $\begin{array}{c}\text { MC-RR } \\
{\left[\mu \mathrm{g} \cdot \mathrm{L}^{-1}\right]}\end{array}$ & $\begin{array}{c}\text { MC Total } \\
{\left[\mu \mathrm{g} \cdot \mathrm{L}^{-1}\right]}\end{array}$ \\
\hline 1A & 40 & 14.84 & 2.36 & 6.4 & 23.6 \\
2A & 40 & 3.24 & 0 & 0 & 3.24 \\
3A & 40 & 14.81 & 3.26 & 48.73 & 66.8 \\
1B & 200 & 74.2 & 11.8 & 32.02 & 118.02 \\
2B & 200 & 16.18 & 0 & 0 & 16.18 \\
3B & 200 & 74.06 & 16.32 & 243.66 & 334.04 \\
\hline
\end{tabular}

Table 2

The species composition and other parameters of the crude cyanobacterial biomass, sampled from natural water bodies in the Czech Republic, and used for toxicity tests performed on Japanese medaka, Oryzias latipes

\begin{tabular}{|c|c|c|c|c|c|c|}
\hline $\begin{array}{l}\text { Sample } \\
\text { No. }\end{array}$ & $\begin{array}{l}\text { Proportion and composition } \\
\text { of cyanobacteria }\end{array}$ & $\begin{array}{c}\mathrm{Chl}-a \\
{\left[\mu \mathrm{g} \cdot \mathrm{L}^{-1}\right]}\end{array}$ & $\begin{array}{l}\mathrm{MC}-\mathrm{LR} \\
{\left[\mu \mathrm{g} \cdot \mathrm{g}^{-1}\right]}\end{array}$ & $\begin{array}{l}\mathrm{MC}-\mathrm{YR} \\
{\left[\mu \mathrm{g} \cdot \mathrm{g}^{-1}\right]}\end{array}$ & $\begin{array}{l}\text { MC-RR } \\
{\left[\mu \mathrm{g} \cdot \mathrm{g}^{-1}\right]}\end{array}$ & $\begin{array}{l}\mathrm{MC} \text { total } \\
{\left[\mu \mathrm{g} \cdot \mathrm{g}^{-1}\right]}\end{array}$ \\
\hline 1 & $\begin{array}{l}\text { 90\% in total phytoplankton: } \\
\text { Microcystis flos-aquae } 45 \% \\
\text { Microcystis aeruginosa } 25 \% \\
\text { Woronichinia naegeliana } 15 \% \\
\text { Anabaena sigmoidea } 15 \%\end{array}$ & 17.7 & 371.0 & 59.0 & 160.1 & 590.1 \\
\hline 2 & $\begin{array}{l}95 \% \text { in total phytoplankton: } \\
\text { Microcystis aeruginosa } 41 \% \\
\text { Woronichinia naegeliana } 41 \%\end{array}$ & 10.4 & 80.9 & 0.0 & 0.0 & 80.9 \\
\hline 3 & $\begin{array}{l}95 \% \text { in total phytoplankton: } \\
\text { Microcystis aeruginosa } 70 \% \\
\text { Aphanizomenon flos-aquae } 25 \%\end{array}$ & 65.7 & 370.3 & 81.6 & 1218 & 1670 \\
\hline
\end{tabular}

Chl- $a=$ chlorophyll- $a$; MC $=$ microcystin [dry weight $]$. 
ProODO (Yellow Springs, OH, USA) to prove no oxygen depletion problem in individual wells.

Statistical analyses. Statistical analyses were performed using software products: Microsoft ${ }^{\circledR}$ Office Excel 2003 and StatSoft, Inc. (2001) STATISTICA ${ }^{\circledR} \mathrm{Cz}$ version 6 . Differences in hatching rates and malformation occurrence were evaluated using $\chi^{2}$-test. Differences in mean values of embryonic development duration were compared by Student's $t$-test (with previous verification of homogeneity of variances by $F$-test and normality by Kolmogorov-Smirnov test).

\section{RESULTS}

Optimization of egg numbers in a testing well. Significantly $(P<0.05)$ highest hatching rates $(88.33 \pm$ $19.40 \%$ ) were achieved in wells with 4 eggs (Table 3 ). Generally, the hatching rate was lowest $(43.33 \pm 50.40 \%)$ in single egg per well and increased until four eggs per well. From this point, the hatching rates declined again on $65.45 \pm 33.34$ and $74.96 \pm 19.19 \%$ in wells with 5 and 6 eggs, respectively.

The longest duration of embryonic development was recorded in 4 and 5 eggs per well treatments with $472 \pm 130 \mathrm{D}^{\circ}$ and $475 \pm 90 \mathrm{D}^{\circ}$, respectively, which differed significantly $(P<0.05)$ from all remaining variants. By contrast, significantly lowest $(P<0.05)$ values, compared to other variants, were found in 6 eggs per well $\left(346 \pm 97 \mathrm{D}^{\circ}\right)$.

Cyanobacterial biomass toxicity tests. The hatching rates $81.25 \pm 24.13 \%$, achieved in the control group, were significantly different from the majority of samples with cyanobacterial biomass (Table 4), in particular in compar- ison with B samples $(P<0.01)$ containing $200 \mathrm{mg} \cdot \mathrm{L}^{-1}$. Medaka eggs hatching rates ranged from $20.83 \pm 29.84 \%$ to $54.17 \pm 35.09 \%$ in $2 \mathrm{~B}$ and $1 \mathrm{~B}$, respectively.

Hatching of free embryos commenced at $179 \mathrm{D}^{\circ}$ post fertilization in control and similarly at $152-178 \mathrm{D}^{\circ}$ in lower cyanobacterial concentrations A $\left(40 \mathrm{mg} \cdot \mathrm{L}^{-1}\right)$. In higher concentrations $\left(\mathrm{B}, 200 \mathrm{mg} \cdot \mathrm{L}^{-1}\right)$, hatching onset was considerably delayed $\left(230-280 \mathrm{D}^{\circ}\right)$.

The hatching rates decreased in higher concentrations of cyanobacterial biomass $\left(\mathrm{B}, 200 \mathrm{mg} \cdot \mathrm{L}^{-1}\right)$ compared to lower concentrations $\left(\mathrm{A}, 40 \mathrm{mg} \cdot \mathrm{L}^{-1}\right)$. In samples 2 and 3 , the difference was proved to be significant $(P<0.01)$ whilst insignificant $(P>0.05)$ in sample 1 .

No deformities or other malformations were recorded in the control group and the total percentage of afflicted embryos (i.e., unhatched, dead and/or malformed) was $18.7 \%$ (Table 4). In lower cyanobacterial concentrations $\left(\mathrm{A}, 40 \mathrm{mg} \cdot \mathrm{L}^{-1}\right)$, the percentage of deformities amongst hatched embryos ranged from $6.3 \%$ to $11.8 \%$ in $3 \mathrm{~A}$ and $1 \mathrm{~A}$, respectively. In higher cyanobacterial concentrations $\left(\mathrm{B}, 200 \mathrm{mg} \cdot \mathrm{L}^{-1}\right)$, the occurrence of deformities was not recorded in $2 \mathrm{~B}$. However in $3 \mathrm{~B}$ and $1 \mathrm{~B}$, the percentage of deformities amongst hatched embryos was $30.0 \%$ and $40.9 \%$, respectively.

\section{DISCUSSION}

The optimization experiments revealed that significantly $(P<0.05)$ highest rates of hatching were recorded with 4 eggs in one $10-\mathrm{mL}$ incubation well. Obviously this is due to the effect of increased hatching enzyme (Kinoshita et al. 2009) concentration in comparison to

Table 3

Preliminary experiments intended to determine an optimal number of eggs per well (10 mL) for subsequent toxicity tests of the crude cyanobacterial biomass on Japanese medaka, Oryzias latipes

\begin{tabular}{lcccc}
\hline Treatment No. & $\begin{array}{c}\text { No. of eggs } \\
\text { per well }\end{array}$ & $\begin{array}{c}\text { No. } \\
\text { of replicates }\end{array}$ & $\begin{array}{c}\text { Hatching rate } \\
{[\text { mean } \pm \text { SD; } \%]}\end{array}$ & $\begin{array}{c}\text { Duration } \\
{\left[\mathrm{D}^{\circ}\right]}\end{array}$ \\
\hline A & 1 & 30 & $43.3 \pm 50.4^{\mathrm{a}}$ & $403 \pm 60^{\mathrm{a}}$ \\
B & 2 & 18 & $52.8 \pm 36.3^{\text {ad }}$ & $401 \pm 44^{\mathrm{a}}$ \\
C & 3 & 12 & $59.7 \pm 25.1^{\text {ad }}$ & $419 \pm 95^{\mathrm{a}}$ \\
D & 4 & 30 & $88.3 \pm 19.4^{\mathrm{b}}$ & $472 \pm 130^{\mathrm{b}}$ \\
E & 5 & 22 & $65.5 \pm 33.3^{\text {cde }}$ & $475 \pm 93^{\mathrm{b}}$ \\
F & 6 & 18 & $75.0 \pm 19.2^{\mathrm{e}}$ & $346 \pm 97^{\mathrm{c}}$ \\
\hline
\end{tabular}

Degree-days $\left(\mathrm{D}^{\circ}\right)$ correspond to mean daily temperature multiplied by number of days; Values that do not differ significantly $(P<0.05)$ share common superscripts $(\mathrm{a}-\mathrm{e})$.

Table 4

Hatching parameters of Japanese medaka, Oryzias latipes, subjected to complex crude cyanobacterial biomass from natural water bodies in the Czech Republic

\begin{tabular}{lcccc}
\hline Treatment No. & $\begin{array}{c}\text { No. of eggs } \\
\text { per well }\end{array}$ & $\begin{array}{c}\text { No. } \\
\text { of replicates }\end{array}$ & $\begin{array}{c}\text { Hatching rate } \\
{[\text { mean } \pm \text { SD; } \%]}\end{array}$ & $\begin{array}{c}\text { Duration } \\
{\left[D^{\circ}\right]}\end{array}$ \\
\hline A & 1 & 30 & $43.3 \pm 50.4^{\mathrm{a}}$ & $403 \pm 60^{\mathrm{a}}$ \\
B & 2 & 18 & $52.8 \pm 36.3^{\text {ad }}$ & $401 \pm 44^{\mathrm{a}}$ \\
C & 3 & 12 & $59.7 \pm 25.1^{\text {ad }}$ & $419 \pm 95^{\mathrm{a}}$ \\
D & 4 & 30 & $88.3 \pm 19.4^{\mathrm{b}}$ & $472 \pm 130^{\mathrm{b}}$ \\
E & 5 & 22 & $65.5 \pm 33.3^{\text {cde }}$ & $475 \pm 93^{\mathrm{b}}$ \\
F & 6 & 18 & $75.0 \pm 19.2^{\mathrm{e}}$ & $346 \pm 97^{\mathrm{c}}$ \\
\hline
\end{tabular}

Values that do not differ significantly $(P<0.05)$ share common superscripts $(\mathrm{a}-\mathrm{e})$; $\mathrm{D}^{\circ}=$ degree days (post fertilization) correspond to mean daily temperature multiplied by number of days. 
wells containing lower number of eggs. In wells with higher (5 and 6) egg numbers per $10-\mathrm{mL}$ well, the hatching rates declined to $64.5 \%$ and $75.0 \%$, respectively. Despite increased hatching enzyme concentration, the oxygen conditions were probably less favourable reflecting higher egg respiration, and resulting in lower hatching rates.

Immersion exposure of eggs is not widely used in MCs embryotoxicity studies with medaka eggs. Due to the protective role of fish egg chorion, microinjection techniques are often applied in medaka (Jaquet et al. 2004, HuynhDelerme et al. 2005) and also zebrafish (Berry et al. 2009). The mentioned study with zebrafish proved that cylindrospermopsin was toxic to zebrafish embryos only when injected directly into embryos but not by direct immersion at concentrations up to $50 \mu \mathrm{g} \cdot \mathrm{L}^{-1}$ (Berry et al. 2009). Immersion techniques focused on microcystin embryotoxicity have been used in common carp, Cyprinus carpio (see Palíková et al. 2003, 2007a, b) but also in other fish species such as loach, Misgurnus mizolepis (see Liu et al. 2002). Although immersion embryotoxicity tests with medaka eggs are not routinely used, studies of Llewellyn et al. (1977) and Rakotobe et al. (2010) demonstrated good sensitivity to aflatoxin $\mathrm{B}_{1}$ and Madagascar yam (Dioscorea antaly) extracts, which proved medaka embryos as a valuable model fish to analyze the effects of natural toxins.

Our screening tests of complex crude cyanobacterial biomass embryotoxicity on Japanese medaka eggs proved their feasibility for this kind of bioassays. Medaka embryos have been successfully used for tests of toxins contained in the complex samples, composed mainly of Microcystis species, which is one of the most common and dominant bloom-forming cyanobacteria. The lowest embryotoxic effect both in terms of hatchability and malformation occurrence was recorded in lower cyanobacterial biomass concentration $\left(40 \mathrm{mg} \cdot \mathrm{L}^{-1}\right)$ of the sample $2 \mathrm{~A}$ which was composed mostly of Microcystis aeruginosa (41\%) and Woronichinia naegeliana (41\%) and contained the lowest MC concentration $\left(3.24 \mu \mathrm{g} \cdot \mathrm{L}^{-1}\right)$. No difference has been proved between the hatching rates compared to control however the percentage of afflicted (deformities + dead/unhatched) embryos was considerably higher in exposed embryos. On the contrary, the embryotoxic effect of higher cyanobacterial biomass concentration $\left(200 \mathrm{mg} \cdot \mathrm{L}^{-1}, 16.18 \mu \mathrm{g} \cdot \mathrm{L}^{-1} \mathrm{MC}\right)$ in the sample $2 \mathrm{~B}$ resulted in decreased rates of hatchability, increased occurrence of afflictions and significantly prolonged duration of embryonic development $(P<0.001)$.

Higher concentration $\left(\mathrm{B}, 200 \mathrm{mg} \cdot \mathrm{L}^{-1} \mathrm{dw}\right)$ of cyanobacterial biomass samples resulted in lower hatchability (Table 4) compared to lower concentrations (A, $40 \mathrm{mg} \cdot \mathrm{L}^{-1} \mathrm{dw}$ ). The effect was most apparent in samples 2 and 3 , where the hatching rates were significantly $(P<0.01)$ lower in $\mathrm{B}$ samples. These differences in hatchability could be related to the content of MCs in A and corresponding B biomasses (Table 2) but more experiments would be needed to fully confirm direct impacts of MCs in the mixture on medaka embryos. Very high mortality of eggs (almost
$80 \%$ ) was recorded in the sample $2 \mathrm{~B}$, which affected the overall outcome of the experiment, i.e., minimum number of malformations observed at this treatment. Increased mortality of embryos may be partly explained by observations of Huynh-Delerme et al. (2005) who concluded that in MC-LR treated medaka embryos, the terminal differentiation disorders appeared in all organs associated with the digestive tract. The occurrence of embryonic defects (composed of unhatched/dead and malformed embryos Table 4) was higher in higher $\mathrm{MC}$ concentration (B, $200 \mathrm{mg} \cdot \mathrm{L}^{-1} \mathrm{dw}$ ) but it should be kept in mind that higher B concentrations contained elevated concentrations of both MCs as well as other components of complex cyanobacterial bloom, which could also play a role in embryotoxicity. The conclusions of Palíková et al. (2007a) did not indicate any direct relation between MCs concentrations and cyanobacterial embryotoxicity for common carp. In their studies, complex cyanobacterial biomass and crude aqueous extracts from four different natural water blooms were more toxic than equivalent concentrations of microcystin-containing fractions concentrated by the solid phase extraction, and the highest (100\%) cumulative mortality rates were recorded for biomass of $120 \mathrm{mg} \cdot \mathrm{L}^{-1}$ followed by $20 \%-80 \%$ mortality rates for biomass (dw) of $80 \mathrm{mg} \cdot \mathrm{L}^{-1}$. Study of Palíková et al. (2007b) indicates high sample-specific toxicity with no direct relation to MCs contents. Further, the most prevalent effects occurred at samples dominated by filamentous cyanobacteria Aphanizomenon and Planktothrix, which were not included in the present investigation.

In our tests, the highest percentage of malformations (40.9\%) appeared in 1B (200 mg $\cdot \mathrm{L}^{-1} \mathrm{dw}, 118.02 \mu \mathrm{g} \cdot \mathrm{g}^{-1}$ $\mathrm{MCs})$. The occurrence of abnormalities is a frequent concomitant of cyanobacterial toxicity to fish embryos. Their patterns (curved body and tail, pericardial edema, yolk sac dropsy etc.) are usually similar regardless of the fish species as it was shown in carp (Palíková et al. 2003), loach (Liu et al. 2003), and zebrafish (Oberemm et al. 1997, Berry et al. 2007). Liu et al. (2003) mentioned also abnormal hatching as a result of embryotoxicity impact. In medaka, considerably delayed onset of hatching was recorded in higher (dw) (and MCs) concentrations. Embryos started hatching at 179, 152-178, but at 230-280 $\mathrm{D}^{\circ}$ in control, A (40 $\left.\mathrm{mg} \cdot \mathrm{L}^{-1} \mathrm{dw}\right)$ and B samples $\left(200 \mathrm{mg} \cdot \mathrm{L}^{-1} \mathrm{dw}\right)$, respectively. Alterations in time span of embryonic development due to the cyanobacterial toxicity were recorded also in rainbow trout, Oncorhynchus mykiss, and amphibian axolotl, Ambystoma mexicanum (see Oberemm et al. 1999).

The observations in the immersion toxicity tests might be also affected by changes in oxygen levels due to the decomposition of cyanobacterial biomass. These processes result in lower oxygen saturation, and the impact of oxygen saturation in water on the extent of cyanobacterial toxicity was discussed previously. Palíková et al. (2007a) showed increased mortality of carp embryos in experimental groups subject to the impact of complex biomass and aqueous crude extract of cyanobacteria without 
aeration in comparison to groups with aeration. Similar indications were recorded in the initial experiments with medaka egg hatchability, where lower oxygen concentrations were likely to decrease hatching rates in the concentration $>4$ eggs in $10 \mathrm{~mL}$ despite the positive impact of hatching enzyme.

Due to their easy availability in uniform (and known) age during the whole growing season and sufficient sensitivity in immersion embryotoxicity tests, Japanese medaka eggs seem to be a valuable for rapid screening bioassays of embryotoxic effects of crude cyanobacterial biomass.

\section{ACKNOWLEDGEMENTS}

The study was supported by the South Bohemian Research Center of Aquaculture and Biodiversity of Hydrocenoses (Jihočeské výzkumné centrum akvakultury a biodiverzity hydrocenóz) CENAKVA CZ.1.05/2.1.00/01.0024, GA JU 047/2010/7, MSM 6007665809 and by the National Agency of Agricultural Research, Czech Republic (Národní agentura pro zemědělský výzkum) NAZV project QH 81012.

\section{RERERENCES}

Anonymous 1998. OECD Guideline for testing of chemicalsfish, short-term toxicity test on embryo and sac-fry stages. OECD 212.

Anonymous 1999a. ČSN EN ISO 7346-1 (757761). Jakost vod - Stanovení akutní letální toxicity látek pro sladkovodní ryby [Brachydanio rerio Hamilton-Buchanan (Teleostei, Cyprinidae)] - Č́st 1: Statická metoda. \{Water qualityDetermination of the acute lethal toxicity of substances to freshwater fish [Brachydanio rerio Hamilton-Buchanan (Teleostei, Cyprinidae)]. Part 1: Static method.\} CNI, Prague, Czech Republic. [In Czech.]

Anonymous 1999b. ČSN EN ISO 7346-2 (757761). Jakost vod - Stanovení akutní letální toxicity látek pro sladkovodní ryby [Brachydanio rerio Hamilton-Buchanan (Teleostei, Cyprinidae)] - Část 2: Obnovovací metoda. \{Water quality-Determination of the acute lethal toxicity of substances to freshwater fish [Brachydanio rerio Hamilton-Buchanan (Teleostei, Cyprinidae)]. Part 2: Renewal method.\} CNI, Prague, Czech Republic. [In Czech.]

Babica P., Kohoutek J., Bláha L. Adamovský O., Maršálek B. 2006. Evaluation of extraction approaches linked to ELISA and HPLC for analyses of microcystin-LR, -RR and -YR in freshwater sediments with different organic material content. Analytical and Bioanalytical Chemistry 385 (8): 1545-1551. DOI: $10.1007 / \mathrm{s} 00216-006-0545-8$

Berry J.P., Gantar M., Gibbs P.D.L., Schmale M.C. 2007. The zebrafish (Danio rerio) embryo as a model system for identification and characterization of developmental toxins from marine and freshwater microalgae. Comparative Biochemistry and Physiology C 145 (1): 61-72. DOI: 10.1016/j.cbpc.2006.07.011

Berry J.P., Gibbs P.D.L., Schmale M.C., Saker M.L. 2009. Toxicity of cylindrospermopsin, and other apparent metabolites from Cylindrospermopsis raciborskii and
Aphanizomenon ovalisporum, to the zebrafish (Danio rerio) embryo. Toxicon 53 (2): 289-299.

DOI: $10.1016 / j$.toxicon.2008.11.016

Bischoff K. 2001. The toxicology of microcystin-LR: Occurrence, toxicokinetics, toxicodynamics, diagnosis and treatment. Veterinary and Human Toxicology 43 (5): 294-297.

Burýšková B., Hilscherová K., Babica P., Vršková D., Maršálek B., Bláha L. 2006. Toxicity of complex cyanobacterial samples and their fractions in Xenopus laevis embryos and the role of microcystins. Aquatic Toxicology 80 (4): $346-354$.

DOI: $10.1016 / j$.aquatox.2006.10.001

Djediat C., Malécot M., de Luze A., Bernard C., PuiseuxDao S., Edery M. 2010. Localization of microcystin-LR in medaka fish tissues after cyanotoxin gavage. Toxicon 55 (2-3): 531-535. DOI: 10.1016/j.toxicon.2009.10.005

Gregor J., Maršálek B. 2004. Freshwater phytoplankton quantification by chlorophyll $a$ : a comparative study of in vitro, in vivo and in situ methods. Water Research 38 (3): 517-522.

DOI: 10.1016/j.watres.2003.10.033

Helmstetter M.F., Maccubin A.E., Alden R.W.III. 1996. The medaka embryo-larval assay: an in vivo assay for toxicity, teratogenicity and carcinogenicity. Pp. 93-122. In: Ostrander G.K. (ed.) Techniques in aquatic toxicology. Lewis Publishers Boca Raton, New York, London, Tokyo.

Huynh-Delerme C., Edery M., Huet H., Puiseux-Dao S., Bernard C., Fontaine J.-J., Crespeau F., de Luze A. 2005. Microcystin-LR and embryo-larval development of medaka fish, Oryzias latipes. I. Effects on the digestive tract and associated systems. Toxicon 46 (1): 16-23.

DOI: 10.1016/j.toxicon.2005.03.009

Jacoby J.M., Collier D.C., Welch E.B., Hardy F.J., Crayton M. 2000. Environmental factors associated with a toxic bloom of Microcystis aeruginosa. Canadian Journal of Fisheries and Aquatic Sciences 57 (1): 231-240.

DOI: $10.1139 /$ cjfas-57-1-231

Jacquet C., Thermes V., de Luze A., Puiseux-Dao S., Bernard C., Joly J.-S., Bourrat F., Edery M. 2004. Effects of microcystin-LR on development of medaka fish embryos (Oryzias latipes). Toxicon 43 (2): 141-147.

DOI: 10.1016/j.toxicon.2003.11.010

Kinoshita M., Murata K., Naruse K., Tanaka M. 2009. Medaka. Biology, management, and experimental protocols. Wiley-Blackwell, Ames.

Lecoz N., Malécot M., Quiblier C., Puiseux-Dao S., Bernard C., Crespeau F., Edery M. 2008. Effects of cyanobacterial crude extracts from Planktothrix agardhii on embryo-larval development of medaka fish, Oryzias latipes. Toxicon 51 (2): 262-269.

DOI: 10.1016/j.toxicon.2007.09.011

Liu Y., Song L., Li X., Liu T. 2002. Toxic effects of microcystin-LR on embryo-larval and juvenile development of loach, Misguruns mizolepis Gunthe. Toxicon 40 (4): 395-399.

DOI: 10.1016/S0041-0101(01)00173-8

Llewellyn G.C., Stephenson G.A., Hofman J.W. 1977. Aflatoxin $\mathrm{B}_{1}$ induced toxicity and teratogenicity in Japanese 
medaka eggs (Oryzias latipes). Toxicon 15 (6): 582-587. DOI: 10.1016/0041-0101(77)90111-8

Maršálek B., Bláha L. 2000. Microbiotests for cyanobacterial toxins screening. Pp. 519-526. In: Persoone G., Janssen C., De Coen W. (eds.) New microbiotests for routine toxicity screening and biomonitoring. Kluwer Academic/Plenum Publishers, New York, NY, USA.

Maršálek B., Bláha L., Hindák F. 2000. Review of toxicity of cyanobacteria in Slovakia. Biologia Bratislava 55 (6): 645-652.

Maršálek B., Bláha L., Turánek J. 2001. Microcystin LR and total microcystins in Czech reservoirs during 1993-1998. Pp. 55-62. In: Chorus I. (ed.) Cyanobacterial toxins. Springer Verlag, Berlin.

Oberemm A., Fastner J., Steinberg C.E.W. 1997. Effects of microcystin-LR and cyanobacterial crude extracts on embryo-larval development of zebrafish (Danio rerio). Water Research 31 (11): 2918-2921.

DOI: 10.1016/S0043-1354(97)00120-6

Oberemm A., Becker J., Codd G.A., Steinberg C. 1999. Effects of cyanobacterial toxins and aqueous crude extracts of cyanobacteria on the development of fish and amphibians. Environmental Toxicology 14 (1): 77-87.

DOI: $\quad 10.1002 /($ SICI) 1522-7278(199902)14:1<77::AIDTOX11>3.0.CO;2-F

Palíková M., Navrátil S., Maršálek B., Bláha L. 2003. Toxicity of crude extract of cyanobacteria for embryos and larvae of carp (Cyprinus carpio L.). Acta Veterinaria Brno 72 (3): 437-443. DOI: 10.2754/avb200170040443
Palíková M., Krejčí R., Hilscherová K., Burýšková B., Babica P., Navrátil S., Kopp R., Bláha L. 2007a. Effects of different oxygen saturation on activity of complex biomass and aqueous crude extract of cyanobacteria during embryonal development in carp (Cyprinus carpio L.). Acta Veterinaria Brno 76 (2): 291-299. DOI: $10.2754 /$ avb200776020291

Palíková M., Krejčí R., Hilscherová K., Babica P., Navrátil S., Kopp R., Bláha L. 2007b. Effect of different cyanobacterial biomasses and their fractions with variable microcystin content on embryonal development of carp (Cyprinus carpio L.). Aquatic Toxicology 81 (3): 312-318.

DOI: 10.1016/j.aquatox.2007.01.001

Rakotobe L., Berkal M., Huet H., Djediat C., Jeannoda V., Bodo B., Mambu L., Crespeau F., Edery M. 2010. Effects of Madagascar yam extracts, Dioscorea antaly, on embryolarval development of medaka fish, Oryzias latipes. Toxicon 55 (1): 87-91.

DOI: $10.1016 /$ j.toxicon.2009.07.002

Scholz S., Fischer S., Gündel U., Küster E., Luckenbach T., Voelker D. 2007. The zebrafish embryo model in environmental risk assessment - applications beyond acute toxicity testing. Environmental Science and Pollution Research 15 (5): 394-404.

DOI: $10.1007 / \mathrm{s} 11356-008-0018-\mathrm{Z}$

Received: 2 September 2011

Accepted: 26 November 2011

Published electronically: 31 December 2011 